\title{
THE TEACHER'S ROLE AND PROFESSIONAL DEVELOPMENT
}

\author{
Dr. Danijela Makovec, University of Ljubljana, Faculty of Arts, \\ Department of Educational Sciences, Ljubljana, Slovenia \\ E- mail: danijela.makovec@ff.uni-lj.si
}

A R T I C L E I N F O
Original Research
Received: March, 19.2018.
Revised: May, 25.2018.
Accepted: June, 19.2018.
doi:10.5937/ijcrsee1802033M
UDK
371.15
Keywords:
teacher's professional identity,
professional development of teachers,
expectations,
beliefs.

\begin{abstract}
A B S T R A C T
The text addresses the theme of teachers' professional development. The role of a teacher is defined by cultural and social events and the environment, and they influence the differences that occur in the concept of teacher roles within different cultures, societies, including the geographic environment. Thus, in the first part of the paper, based on an analysis of the literature, we identify factors that significantly influence teachers' perception of their role and consequently, determine their professional identity. In the second part, based on the results of the empirical research, we show that factors such as teachers' beliefs about their own qualifications, as well as years of work experience and subject area, statistically significantly influenced the development of the teachers' professional identity. The main findings of the study are that teachers with several years of service experience feel better qualified to perform their duties (tasks related to planning and teaching were rated the most highly) than teachers with less work experience, and that teachers with more work experience evaluated the claims related to their educational activity statistically significantly higher. An important finding is that teachers define their professional identity and consequently, their role through their personality traits, which shows that we must not ignore teachers' personality traits, as they play an important role in teachers' professional development and identity.
\end{abstract}

(C) 2018 IJCRSEE. All rights reserved.

\section{INTRODUCTION}

Regardless of which attitudes we strive for in teaching, the teacher always plays an important role. According to Adams (1970), the role of a teacher relates to what individuals actually do (their behavior), while the role of an individual can also be influenced by the expected actions of individuals (p. 121), in particular the individuals' own expectations (i.e., the teachers themselves) or the expectations of others (pupils, students, parents, colleagues, school leaders, society, etc.).

The role of the teacher is never uniquely defined, and its definition is influenced by many factors. It is defined by cultural and

Corresponding Author

Dr. Danijela Makovec, University of Ljubljana, Faculty of Arts, Department of Educational Sciences, Ljubljana, Slovenia, E- mail: danijela.makovec@ff.uni-lj.si

\section{cc) (†) $\ominus$}

This work is licensed under a Creative Commons Attribution - NonCommercial - NoDerivs 4.0. The article is published with Open Access at www.ijcrsee.com social events and the environment, and both influence the differences that occur in the conceptions of the roles of teachers within different cultures and societies, including the geographic environment.

The factors that influence the role of the teacher are internal and external. Internal factors include those that influence a teacher's own perception of his or her role. External factors include the views and expectations of the role of the teacher, which arise within other stakeholders, such as pupils, parents, colleagues, school leaders, and the public. Both types of factors are also an important part of a teacher's professional identity. Internal factors that influence the understanding of the teacher's role are created by the teachers themselves and can be classified into two categories: the teacher's own beliefs about which role is important and the teacher's expectations for his or her role.

Teachers' beliefs are beliefs teachers from different sources develop about their role. The beliefs are often secular and not tied to expert knowledge, but they are also considered durable and resistant to changes (McRob- 
bie and Tobbin, 1995; Tobin and La-Master, 1995). Nespor suggested that beliefs have stronger affective and evaluative components than knowledge and that affect typically operates independently of the cognition associated with knowledge (Nespor in Pajares, 1992, p. 309). Above all, due to the emotional charge of beliefs, they often play a central role in organizing knowledge and defining the role of teachers (Beijaard, 1995, p. 245). According to Calderhead and Robson (1991), beliefs that determine the interpretation of individual subjects and concrete behaviors in a class acquired during teacher education play an important role in determining how they will be translated into the knowledge of the beginner teacher, and they determine the way a teacher works in the classroom. Although an individual's knowledge is based on objective facts, beliefs are based on evaluation and judgments (Pajares, 1992, p. 313), and because of the greater emotional charge, beliefs can have a greater influence on how teachers understand their role. A particularly strong role is played by the beliefs of beginner teachers who are more likely (than teachers with more experience) to find themselves in situations that are new and base their reactions on their own experience.

Teachers' expectations determine the understanding of their own role, as the sense of efficiency in the work that teachers experience can also depend on how they see themselves as professionals (Ben-Peretz, Mendelsona, and Kronb, 2003, p. 278). Teachers' expectations are influenced by the experience and knowledge they acquire during their education for the teaching profession, as during this period teachers begin to build their professional image of themselves as a teacher. Therefore, many authors (Kagan, 1992; Samuel and Stephens, 2000; Rodrigues et al., 2018). emphasize the importance of quality education in the shaping expectations and the idea of their role. In addition to the education experience, teachers' expectations are influenced by the context of teaching. In a 2003 study, BenPeretz and colleagues found that teachers who teach pupils with lower abilities see their role differently from teachers who instruct pupils with higher abilities. Teachers' expectations for their role in the class are also directly related to their professional identity. Authors who studied these areas agreed that one of the important elements on which teachers build their professional identity, is also role, that he attaches to himself or attributed to him by surroundings (Goodson and Cole, 1994; Nias,
1989; Volkmann and Anderson, 1998).

\subsection{Teacher professional development}

Valenčič Zuljan (2001) defined the professional development of teachers as:

"...the process of meaningful and lifelong learning, in which teachers develop their conceptions and change their teaching practice; it is a process that involves the teacher's personal, professional and social dimension and represents the teacher's progress towards critical independent, responsible decisionmaking and behavior." (p. 131)

Within the framework of professional development, teachers change, improve in the professional field, as well as change, improve, and complement their pedagogical competences and behavior, and change as a person. According to Kalin (2006), a teacher is:

"...committed to continuous professional development and working with others (colleagues), is aware of the connection between one's own development and the development of students and sees its role also outside the class: it builds the connection with people in the local community and society as a whole, with management bodies and researchers." (p. 174)

Beijaard (1995) stated that a teacher's professional identity is composed of three factors: the subject they teach, their relationship with pupils, and their role or role conception (p. 282). The latter is built in relation to the object and the relation with pupils and therefore cannot be considered independently of the other two factors. According to Biddle (in Beijaard 2005, p. 293), most interpretations of teachers' roles refer to teachers' tasks, their social position, status, or the status, image, and expectations of other people (especially pupils and parents). Similarly, (Day, 2006, p. 610) stated that the identity of an individual traditionally consists of roles that are defined through the structure of an individual, institution, and society. Teachers' expectations for their role are often associated with the environment's expectations for their role, and finding a distinction between what actually influenced a particular role - the teacher's expectations or the expectations of the surroundings (or the important others) - is difficult. For teachers' expectations for their own role, scholars also consider that expectations can change during teachers' professional careers (which is much easier than changing their own beliefs; 
Beijaard 2005, p. 284), which is largely influenced by the experience they gain. According to Beijaard et al. (2004), this is a completely normal process of developing a professional career path, because teachers' professional development, the important part of which is the teacher's role, continues throughout their career and is not something "which the teacher would have permanently possessed in the unchanged form" (p. 107). Many factors influence the process of change. It can happen spontaneously or with various incentives. In this process, changes do not occur at one time but gradually. Yung, 2001, p. 259 stated that this change occurs in three steps: (1) awareness, (2) comparison with alternatives, and (3) identification of actions that are consistent with the alternatives. Most importantly, the teachers themselves must undertake such a learning process. The key to the whole process is that teachers commit themselves, which means that they allow a changed view of their role, and above all, in particular, they allow themselves to be changed. In the context of professional teacher development, Beijaard and colleagues (2000) identified three roles for the teacher: the teacher as a subject matter expert, the teacher as a pedagogical expert, and the teacher as a didactical expert, which together influence the development of the teacher's role and determine behavior in the classroom. Thus, Beijaard sees teachers as good subject experts with a very strong knowledge base in their subject area (Poom-Valickis, Oder, and Lepik, 2012, p. 235), which is not sufficient, as teachers also need to have didactic knowledge to bring the knowledge of the profession closer to pupils. According to other authors, at the same time, teachers must create also a learning environment that supports students with the optimal use of teaching methods and learning strategies (Radovan, 2011). But nevertheless, teacher is primarily understood as the one who is responsible for designing and managing the learner's learning process (Poom-Valickis, Oder, and Lepik, 2012, p. 235). Whereas "teaching cannot be reduced to mere technical or instrumental measures that are reflected in the learning achievements of pupils, the didactic aspect of teaching must necessarily be linked to the pedagogic, which also includes ethical and moral characteristics" (Beijaard, Verloop, and Vermunt, 2000, p. 751), they also sees the teacher as a pedagogical expert, who emphasizes relations, values, moral and emotional factors. The pedagogical aspect is also important for teachers' personal and professional understanding of their role (Beijaard, 1995):

In our postmodern societies, teachers increasingly face moral, social, and emotional dilemmas, such as how to educate students from different cultures and different social backgrounds, how to proceed with deviant behavior of pupils... Apart from these dilemmas, teachers should be aware of many norms and values involved in their interaction and relationship with students. (Beijaard et al., 2000, p. 752)

The connection between professional and pedagogical-psychological skills in the role of the teacher was also highlighted by Kalin and Šteh. Preservice teachers not "only need the knowledge of [their] subject, but also a good knowledge of pedagogical psychological knowledge, competence in curriculum design, knowledge and control of didactic procedures in the subject area, knowledge of pupils" (Šteh and Kalin, 2006, p. 80). Teacher professional development actually begins with training at the faculty when future teachers begin to create their professional identity, which happens through defining and recognizing the various roles the future teachers will take on as a teacher in the classroom (The process of building a professional identity can be also done through mentoring. Positive effects of mentoring have been proven in the study Gjedia and Gardinier (2018)). Muršak, Javrh, and Kalin (2011) noted that "an important part of a professional identity is the image of an ideal teacher. This ideal is the abstraction of concrete persons and their properties" (p. 72). Therefore, beginner teachers start to build their image based on the knowledge they acquire at the faculty (knowledge of the profession and pedagogical-psychological knowledge), as well as based on their own experience gained through their schooling with different teachers. The emergence of experience is pronounced when teachers find themselves in a new and unknown situation, and they have not gained any knowledge to react in such situations. Thus, the mentioned authors believe that teacher education, care must be taken to acquire knowledge in the field of the profession and soft skills, which we call pedagogical-psychological qualifications:

The issue of teacher education and training relates primarily to the relationship between professional and pedagogical competence... The deletion of the boundary between the two can be dangerous, especially if we proceed from the assumption that the teacher's preparation is merely a matter of the mathematical profession and professional knowl- 
edge, but not the appropriate pedagogical knowledge. (Muršak et al., 2011, pp. 27-28)

The teacher in the classroom is the whole person, an expert in the profession, as well as an expert in the field of pedagogical and psychological knowledge. Only when we take into account both segments can we talk about teachers. In order to be able to manage the profession, it is not enough, authors also write when they write that "teachers who are otherwise exceptional experts in their profession are not and cannot be able to plan and prepare didactically-methodical adjustments of the subject contents themselves, this is appropriately trained" (Muršak et al., 2011, p. 28).

When talking about a teacher in his professional development, we cannot pass certain definitions that explain some necessary characteristics of a proper teacher, highly important for their development and their pursuit of this profession. For example, Fullan (1993) states that a teacher must have skills such as a developed personal vision, the ability to explore and collaborate with others, and be mature. In addition to mastering the professional and didactic knowledge necessary for a teacher's career, Fullan speaks about skills that include a commitment to personal development (Fullan (1993), p. 23). In the "Green Paper on Teacher Education in Europe" (Buchberger, Campos, Kallos, and Stephenson, 2000, p. 19) we find a definition stating that the main components of a professional teacher education program might be the "studies in the sciences of the teaching profession (e.g., educational sciences, Didaktik/Fachdidaktik, literally translated as didactics and subject matter didactics, educational psychology, educational sociology). All of these are closely connected to educational research and aiming at the development of professional problem-solving capacity, a broad repertoire of validated practices to promote and support learning, and a professional code of ethic."

In Slovenia, the development of teacher competencies, according to Marentič Požarnik (2006), is related to three components: cognitive, which encompasses knowledge and understanding; an action that envelops professional skills and emotional motivation which would determine the teacher's attitudes and values, which must keep the individual competences in balance. The author, through the written text, lists five broad sets of competences: communication and relationships, effective teaching, organization and leadership, cooperation with the working and social en- vironment, and, ultimately, professional development. Also, in connection with development of teacher competencies, as explained in the research by the Faculty of Education of the University of Ljubljana, conducted in 2004, the following competencies were identified as the most desirable for the teaching profession: knowledge of the content and methodology in the chosen field, ability to communicate, teamwork, flexible use of knowledge in practice, autonomy, (self-)criticality, self-reflection, (self-)evaluation, endeavor for quality, organizing active and independent learning, training students for effective learning (Razdevšek Pučko and Rugelj, 2006). When speaking about the qualities of the teacher, it is necessary to take into account the fact that we cannot overpower the personality traits of a teacher because, as the authors Kalin and Marentič Požarnik explain in a comprehensive way, the teacher's professional development includes personal development, and one influences the other. This was also written by Pajak and Blase, 1989, p. 296, who found out that many teachers' interpersonal relationships outside of school serve as important sources of support for their professional role. When one of these personal relationships place overwhelming demands upon the teacher's time and energy, their impact becomes negative and the teachers might become isolated from their students and colleagues. Tickle (in Korthagen, 2004) speaks about people's core personal qualities that are important for the teacher, and lists necessary traits for a successful teacher: creativity, trust, care, courage, sensitivity, decisiveness, spontaneity, commitment, and flexibility. A study conducted by S. Arnon and N. Reichel (2007), who also pointed out the inseparability of professional and personality traits, place in the center of an ideal teacher two basic categories:

1 . The teacher's personality whose personal qualities make him into an empathic and attentive teacher, a teacher in the role of a leader, a teacher with a positive attitude towards the profession, who possesses a wideranging, general knowledge in their chosen field and subject matter.

2. A teacher who has obtained professional, academic knowledge of the subject taught, such as: didactic knowledge, educational methodology, with a focus on an individual pupil, or, in other words, a teacher with a vast general knowledge that is also very well-versed in many other areas (p. 450, 451).

In identifying the qualities necessary for the teacher who can do his job well, we must 
be careful that we, in the context of dealing with the professionalism of the teacher, do not consent to reducing the complexity of the teacher's profession to a list of competences and standards. Instead, the teacher should be considered as a whole personality, which is also pointed out by Fullan and Hargreaves, 2000 , p. 45. Although many would be tempted, the answer to the question "what qualities make a good teacher" cannot be found simply in the selection of some teachers' desirable, both personal and professional, characteristics as M. Kovač Šebart (2002) warns Slovenian Educational system about, and it can't be answered by looking only at the "competences," Korthagen wrote in 2004. Problems should always be looked at in a multifaceted, objective way, and some consideration should also be given to factors such as environment, subject area, years of service, etc., and all this should be done in a wider context of studying teacher's professional development.

\subsection{The purpose of the research study}

Based on the theoretical starting points of the identified and mentions authors (such as Beijaard, 1995, Yung, 2001, Muršak et al., 2011) for the factors that influence teachers' professional development, we wanted to examine the extent to which teachers in Slovenian gymnasiums are qualified to perform the individual roles they encounter in their work and how the concept of self-application in teachers is influenced by factors such as years of service and the subject area. These are factors that significantly affect teachers' professional development, which is also shown by other research (eg. Kunst et al. 2018).

\section{MATERIALS AND METHODS}

The research involved teachers from 16 Slovenian general upper secondary education schools. The survey was conducted in November 2014, with a sample of 345 teachers ( 259 , or $76.9 \%$, were female, and 78 , or $23.1 \%$, were male) who taught 23 different subjects. The teachers' work experience ranged from 1 to 36 years (the average length of service was 19 years). The majority of teachers $(277$, or $81.0 \%$ ) had a university degree.

To collect data, we created a question- naire, which consisted of four parts. In the fourth part of the questionnaire, teachers were asked how qualified they felt to perform individual roles. There were six assertions related to the teachers' work. The teachers assessed their qualifications on a 4-point scale, where 1 meant "I'm under-qualified" and 4 "I'm very competent." In identifying teacher roles, we asked teachers how many individual descriptions were related to the role of teacher were involved in their work. Teachers were offered 68 assertions (see appendix) that specifically related to their work and were asked to assess on a 4-point scale how much each description applied, ranging from 1 (meaning "not at all") to 4 ("completely valid"). The data were processed with the SPSS 22.0 software package. The analysis of the variables showed that the distribution of all variables deviated statistically significantly from the standard. Therefore, we used nonparametric versions of statistical tests to check the differences between groups, the Mann-Whitney U test and the KruskalWallis test. With confirmatory factor analysis using structural modeling of equations, we examined the basic assumption about the three dimensionality of the teacher's role, and in the measurement model, we identified seven latent factors, the dimensions of the role of the teacher: training in the profession and its integration into classes (PROF 1), legal-formal aspect of teachers' activity (PROF 2), accurate lesson planning (DID 1), consideration of class specifications (DID 2), educational-disciplinary behavior in class (PED 1), teacher's personal orientation (PED 2), and teacher's value orientation (PED 3). All required fit indicators (absolute $\left(\chi^{2} / \mathrm{df}=2.030\right.$; Root Mean Square Error of Approximation (RMSEA $=0.055)$ ), parsimoniality indicators (Parsimony Normed Fit Index $($ PNFI $=0.716)$ ) and incremental indicators (Non-Normed Fit Index (NNFI = 0.919 , CFI $=0.934)$ ) indicated a good model fit, including that the predictive reliability and validity of the model were appropriate (Makovec Radovan, 2017). 
(IJCRSEE) International Journal of Cognitive Research in Science, Engineering and Education Vol. 6, No. 2, 2018.

\section{RESULTS}

Table 1. Teachers in the sample grouped according to Huberman's five stages of teacher career development

\begin{tabular}{clcc}
\hline Years & Huberman's Phase & f & \% \\
\hline $1-3$ & Survival and discovery & 13 & 3,8 \\
\hline $4-6$ & Stabilization & 22 & 6,4 \\
\hline $7-18$ & Experimentation/activism & 133 & 38,8 \\
\hline $19-30$ & Serenity' or 'conservatism & 128 & 37,3 \\
\hline $31+$ & Disengagement & 47 & 13,7 \\
\hline Total & & $\mathbf{3 4 3}$ & $\mathbf{1 0 0}$ \\
\hline
\end{tabular}

Before we present the results, we examine the teachers' work experience. We grouped the teachers into stages based on the teachers' work experience, according to Huberman's model of teacher career development. The greatest number of teachers $(38.8 \%)$ were in the experimentation/activism and stock taking stage during which teachers "try to raise their influence, [as] they face the limitations of the system and look for new challenges" (Huberman, 1992, p. 127). Slightly fewer teachers $(37.3 \%)$ were in the serenity or conservatism stage, during which teachers are more relaxed and received such things as they are (Huberman, 1992). Therefore, teachers with more experience dominated the sample.

Table 2. Teachers' beliefs about their skills by Huberman's (1992) stages of professional development and years of service

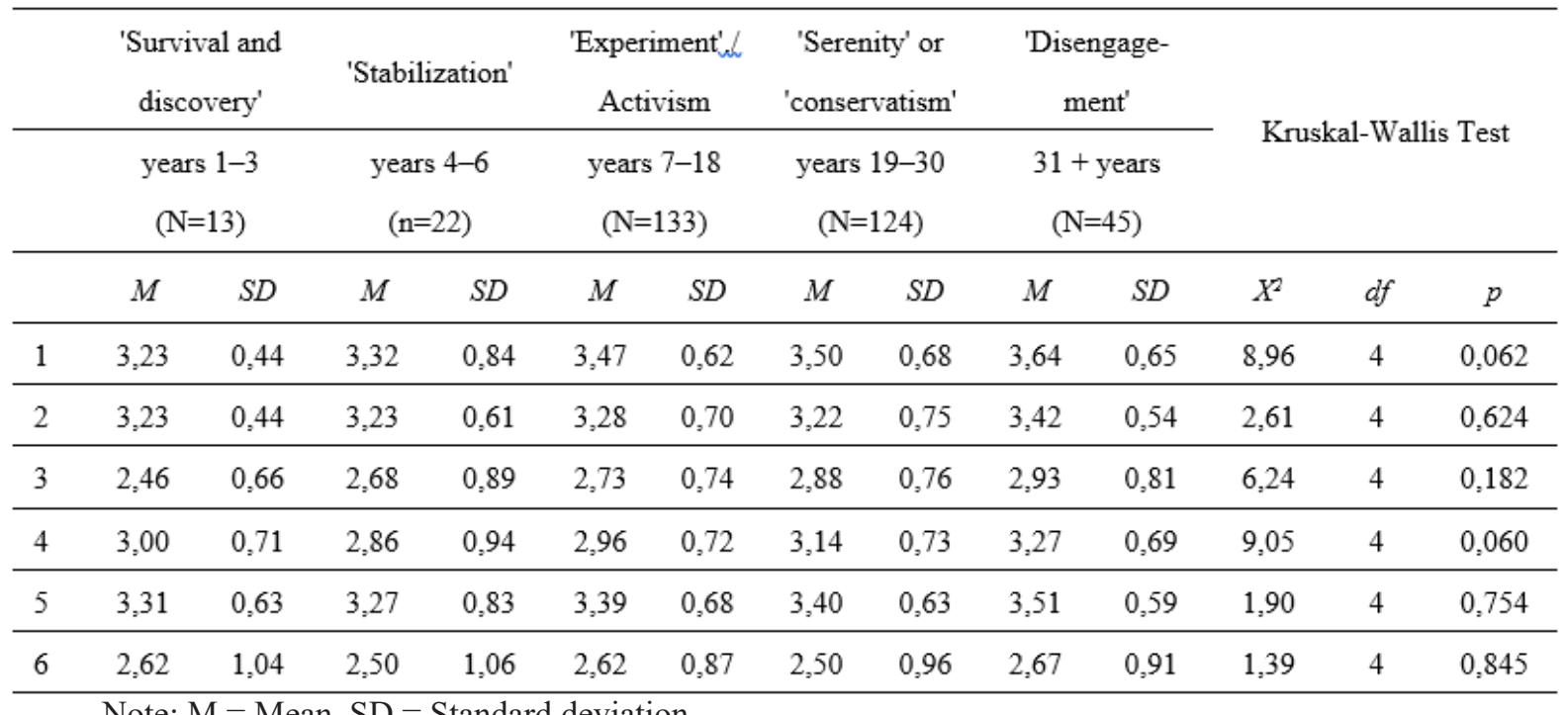

Note: $\mathrm{M}=$ Mean, $\mathrm{SD}=$ Standard deviation

1) Planning and implementing lessons, 2) Using different methods for instruction, 3) Solving educationaldisciplinary issues, 4) Pedagogical activity, 5) Solving professional questions and dilemmas, 6) Publishing professional papers in the field of expertise they teach

Hypothesis about teachers' beliefs about their skills according to their work experience was examined with the KruskalWallis test. There were no statistically significant differences between individual groups, which means that nothing can be said about the impact of years of service on teachers' beliefs about their own competence. Teachers with the most work experience assessed their qualifications as higher than teachers with less experience. In the assertions that the teachers felt most qualified to plan and implement lessons and to solve educational disciplinary problems, a trend of increasing estimates according to years of service was observed. For other assertions, this trend was not observed.

Regardless of years of service, teachers felt the most qualified to perform a direct teaching role, as the teachers in the first three places made claims related to the performance of the lesson, the highest assessment of the assertion "Planning and implementing lessons" $(\overline{\mathrm{x}}=$ 3.49 ), followed by the assertion "Solving professional questions and dilemmas" $(\overline{\mathrm{x}}=3.40)$ and "Using different methods for instruction" $(\bar{x}=3.27)$. These assertions were followed by assertions related to the teacher's pedagogical activity: "Pedagogical activity" $(\overline{\mathrm{x}}=3.06)$ and "Solving educational disciplinary issues" $(\overline{\mathrm{x}}=$ 2.80 ). Teachers felt qualified to publish professional contributions in the field they teach $(\bar{x}=2.58)$. When we asked the respondents, 
who state that they did not feel sufficiently trained, what areas of training they chose, because they felt that they were not sufficiently trained, $25.7 \%$ answered that they decided on education or training from their field of expertise, followed by education in the field of information and communication technology $(10.0 \%)$, education in the field of special pedagogy, working with students with special needs or working with gifted students $(6.1 \%)$, "working in class, classroom management" (4.8\%), and "educational disciplinary issues" $(4.8 \%)$. The item was an open-ended question, to which the teachers freely wrote answers. The category of publishing professional papers in the field of expertise that had previously been considered the area in which the teachers felt the least qualified did not appear in the question areas and topics of education and training that teachers chose.

Table 3. Concepts of a teacher's role by years of service

\begin{tabular}{|c|c|c|c|c|c|c|c|c|c|c|c|c|c|}
\hline & \multicolumn{2}{|c|}{ years 1-3 } & \multicolumn{2}{|c|}{ years $4-6$} & \multicolumn{2}{|c|}{ years $7-18$} & \multicolumn{2}{|c|}{ years $19-30$} & \multicolumn{2}{|c|}{$31+$ years } & \multicolumn{3}{|c|}{ Kruskal-Wallis test } \\
\hline & $\bar{x}$ & $S D$ & $\bar{x}$ & $S D$ & $\bar{x}$ & $S D$ & $\bar{x}$ & $S D$ & $\bar{x}$ & $S D$ & $\chi^{2}$ & $d f$ & $p$ \\
\hline PROF1 & 3,21 & 0,628 & 3,49 & 0,397 & 3,32 & 0,511 & 3,43 & 0,486 & 3,51 & 0,511 & 8,849 & 4 & 0,065 \\
\hline PROF2 & 2,92 & 0,672 & 3,27 & 0,592 & 3,17 & 0,629 & 3,19 & 0,613 & 3,10 & 0,629 & 2,820 & 4 & 0,588 \\
\hline DID1 & 2,85 & 0,642 & 2,74 & 0,554 & 2,71 & 0,617 & 2,81 & 0,689 & 2,90 & 0,617 & 4,643 & 4 & 0,326 \\
\hline DID2 & 3,23 & 0,525 & 3,36 & 0,492 & 3,20 & 0,581 & 3,29 & 0,474 & 3,22 & 0,581 & 1,726 & 4 & 0,786 \\
\hline PED1 & 2,62 & 0,689 & 2,85 & 0,544 & 2,81 & 0,588 & 3,08 & 0,570 & 3,10 & 0,588 & 19,41 & 4 & 0,001 \\
\hline PED2 & 3,36 & 0,419 & 3,58 & 0,506 & 3,50 & 0,530 & 3,54 & 0,444 & 3,52 & 0,530 & 2,737 & 4 & 0,603 \\
\hline PED3 & 3,13 & 0,462 & 3,11 & 0,518 & 3,03 & 0,650 & 3,21 & 0,570 & 3,36 & 0,650 & 9,567 & 4 & 0,048 \\
\hline
\end{tabular}

Note: PROF1=Training in the profession and its integration into classes, PROF2=Legal-formal aspect of teachers'activity, DID1=Accurate lesson planning, DID2=Consideration of class specifications, PED1=Educationaldisciplinary behavior in class, PED2=Teacher's personal orientation, PED3=Teacher's value orientation.

Hypothesis about concepts of a teacher's role in terms of number of years of service was examined with the Kruskal-Wallis test. Statistically significant differences between individual groups were found in two dimensions: "Educational disciplinary behavior in class" (PED 1; $\chi^{2}(\mathrm{p}=0.001, \mathrm{df}=$ $4.000)=19.410)$, in which teachers with more work experience were more involved in their work than teachers with less work experience. When the teachers assessed how many items in the dimension applied in their work, the ratings increased: The teachers with more work experience assessed the items more highly than teachers with less work experience. The second dimension in which statistically significant differences occurred was "Teacher's value orientation" (PED $3 ; \chi^{2}(\mathrm{p}=0.048, \mathrm{df}$ $=4)=9.567$ ): Teachers with more work experience attributed greater importance to this dimension. Teachers with more work experience, especially those with 19 to 30 years of service and between 31 and 40 years of service, emphasized the value of learning content in their classes, encouraged pupils to feel and experience art, and planned their lessons with a reflection on the educational effect of the content. Both dimensions, in which statisti- cally significant differences occurred, are included in the construct Teacher's Pedagogical Excellence. For other constructs with statistically significant differences, we did not record the teachers' the length of service. In general, regardless of length of service, teachers rated the items in the dimension "Precise learning planning" (DID 1) the lowest.

In this study, we wanted to examine whether differences occurred in the conception of the role of the teacher among teachers regardless of subject area. Because of the wide range of subjects taught by the teachers surveyed, we classified the subjects into four categories: Language (Italian, Russian, Slovenian, German, English, French, Spanish, and Latin), Natural Sciences (physics, mathematics, chemistry, biology, and informatics), Social Sciences (psychology, history, sociology, geography, philosophy, and literaryinformation knowledge and pedagogy), and Other (sports, fine arts, and music). 
(IJCRSEE) International Journal of Cognitive Research in Science, Engineering and Education Vol. 6, No. 2, 2018.

Table 4. Understanding the teacher's role with regard to the subject area

\begin{tabular}{lcccccccccccc}
\hline & the language & \multicolumn{2}{c}{$\begin{array}{c}\text { natural science } \\
\text { subjects }\end{array}$} & \multicolumn{2}{c}{ social sciences } & \multicolumn{2}{c}{ other } & \multicolumn{2}{c}{ Kruskal-Wallis test } \\
\hline & \multicolumn{1}{c}{$M$} & $S D$ & $M$ & $S D$ & $M$ & $S D$ & $M$ & $S D$ & $\chi 2$ & $d f$ & $p$ \\
\hline PROF1 & 3,44 & 0,432 & 3,27 & 0,589 & 3,39 & 0,484 & 3,44 & 0,514 & 4,563 & 3 & 0,207 \\
\hline PROF2 & 3,19 & 0,597 & 3,21 & 0,653 & 3,00 & 0,651 & 3,25 & 0,612 & 5,024 & 3 & 0,170 \\
\hline DID1 & 2,86 & 0,626 & 2,69 & 0,666 & 2,57 & 0,688 & 3,07 & 0,523 & 15,829 & 3 & 0,001 \\
\hline DID2 & 3,26 & 0,479 & 3,16 & 0,511 & 3,11 & 0,673 & 3,54 & 0,492 & 21,185 & 3 & 0,000 \\
\hline PED1 & 2,98 & 0,546 & 2,81 & 0,592 & 2,93 & 0,679 & 3,08 & 0,603 & 5,787 & 3 & 0,122 \\
\hline PED2 & 3,50 & 0,526 & 3,56 & 0,489 & 3,44 & 0,484 & 3,59 & 0,423 & 3,742 & 3 & 0,291 \\
\hline PED3 & 3,27 & 0,559 & 2,94 & 0,613 & 3,13 & 0,625 & 3,18 & 0,534 & 14,631 & 3 & 0,002 \\
\hline
\end{tabular}

We also checked hypothesis about understanding the teacher's role regarding subject area with the Kruskal-Wallis test and found statistically significant differences between individual groups of objects in three dimensions: "Precise planning of lessons" (DID $1),\left(\chi^{2}(p=0.001, d f=3.000)=15.829\right)$. This dimension included the items "Detailed planning of teaching," "Structuring lessons after didactic stages," "Writing preparation for each lesson individually," and "Defining operational learning objectives for each lesson." The highest ratings were given by Other teachers, followed by Language teachers and then Natural Sciences teachers. The lowestrated items in this dimension were by Social Sciences teachers.

The second dimension in which there were statistically significant differences is the dimension "Taking into account the specificity of a class" (DID 2$),\left(\chi^{2}(\mathrm{p}=0.000, \mathrm{df}=\right.$ $3.000)=21.185)$. Items "Adapting teaching to the individual characteristics of students" and "Taking into account the specificity of the class" were rated highest by Other teachers, followed by Language teachers and then Natural Sciences teachers. The lowest ratings were from Social Sciences teachers.

Statistically significant differences occurred in one dimension, "Teacher's value orientation" (PED 3), $\left(\chi^{2}(\mathrm{p}=0.002, \mathrm{df}=3.000)\right.$ $=14.631)$. "Teacher's reflection on the curriculum on the educational effect of the content," "Encouraging the sensitivity to experiencing or expressing works of art," and "Emphasizing the valuable dimension of learning content during classes" were assertions in this dimension. The Language teachers ranked the assertions the highest followed by Other teachers and Social Sciences teachers. Natural Sciences teachers ranked the assertions the lowest.

For other dimensions, there were no statistically significant differences between teachers of different categories of subjects. The dimension "Teacher's personal orientation," which included the assertions "Clearly established rules of discipline and behavior in the classroom," "Consistency," and "Determination" of teachers, was rated higher than the other dimensions regardless of the teachers' subject area.

\section{DISCUSSIONS}

In the study, according to the theoretical starting points, we examined the extent to which teachers' professional development is influenced by belief in their own qualifications and factors such as length of service and subject area. The teachers were classified into five groups based on Huberman's model of professional development. In this sample, $3.8 \%$ of teachers had 1 to 3 years of work experience (survival and discovery), $6.4 \%$ had 4 to 6 years (stabilization), $38.8 \%$ had between 7 and 18 years (experimentation/activism and stock taking), $37.3 \%$ had 19 to 30 years (serenity or conservatism), and $13.7 \%$ had between 30 and 40 years (disengagement).

First, we wanted to examine the extent to which teachers feel qualified to perform a particular role, because we believe that a sense of competence can determine the perception of a particular role more than that which is more at the forefront of the teacher's work. We assumed that among the identified roles, teachers felt most qualified to perform a direct instructive role. Although statistically significant differences were not found, the results confirmed our assumption, as teachers ranked as the top three the items directly related to the implementation of the lesson: "Planning and implementing lessons ( $\overline{\mathrm{x}}=3.49)$, "Solving professional questions and dilemmas" $(\overline{\mathrm{x}}=3.40)$, and "Using different methods for in- 
struction" $(\overline{\mathrm{x}}=3.27)$. Fewer teachers feel that they are trained for educational activities, and very few to publish professional papers in the field of expertise they teach. Given the options offered, the teachers' choices seem somewhat logical, as the direct teaching role is the one in which teachers spend most of their time and which is ultimately their central task. The sense of competence is certainly influenced by teachers' knowledge of a particular field, a particular role. And of course, teachers who have more knowledge in a particular field also feel more competent in that area. Lachner et all. (2016) divided teachers' knowledge, on which effective learning is based, into three knowledge bases: knowledge of the content (where the teacher's deep understanding of the subject is taught, for example, understanding of concepts and principles that form a discipline); general pedagogical knowledge, which includes knowledge about the nature of learning, learning processes, and different teaching methods (knowledge that could be classified as teachers' didactic excellence); and pedagogical knowledge about content, which encompasses knowledge about how best to explain the content to pupils, as well as knowledge about possible misconceptions that may arise among pupils (this type of knowledge could be placed in our definition of teachers' didactic excellence). The sum of all three forms a teacher's qualifications and allows teachers to quickly identify important patterns in the classroom, based on which teachers also make decisions about the course of instruction (Putnam in Lachner et al., 2016, p. 198). More recent research into this knowledge added also competence in the use of information and communication technology (ICT), which complements the teacher's didactic competence (Radovan and Kristl, 2017). Lachner's finding also coincides with our assumption that the knowledge an individual has also influences his or her sense of competence, which has also been shown in the field for which teachers feel the least qualified: publishing professional papers in the field of expertise that they teach. Publication of professional contributions by teachers in Slovenia brings extra promotion points, but it is the task it is a task that teachers choose less often. Considering that in the study teachers stated that they feel the least qualified for this role, we checked whether the same topic appeared in the areas of education or training that the teachers chose most often. A review of the training showed that training or education where teachers acquire knowledge to publish professional contributions did not appear among our respondents, which, in turn, indicated that teachers did not express interest in such training. Teacher training in publishing professional contributions is also ignored by the state. In the catalog of programs of further education and training of professional staff in education for the 2016/2017 school year, we did not find any training that addresses this topic. In addition to the aforementioned knowledge teachers should also possess at least a basic knowledge of methodology in order to be able to systematically monitor and analyze their own practice, as well as to introduce their work in their professional papers (Podgornik and Vogrinc, 2017, p. 11). By publishing professional papers, teachers share their experiences and knowledge with others, which is an excellent opportunity for examples of good practice to expand, with ideas and new knowledge acquired by other teachers. Against this background, and regarding the indicated shortcoming in teachers and taking into account that teachers can also gain promotion points, at the expense of publishing professional articles, it would certainly be sensible for teachers to be offered such education or training.

Among the study, we also assumed that when considering the role of a teacher, there would be differences in the subject area and the number of years of service of individual teachers, as the subject area and the teacher's work experience play an important role during a teacher's professional development. Thus, we assumed that teachers with more work experience would attribute greater importance to teachers' pedagogical excellence, which is mainly the educational dimension of the teacher's role. The results showed that statistically significant differences between groups occurred in two dimensions: "Educational-disciplinary behavior in the classroom" and "Teacher's value orientation." Both were classified as Teacher's Pedagogical Excellence. In interpreting the two roles, in which statistically significant differences were found, we used Huberman's career development model. Thus, for the dimension "Childdisciplinary behavior in class" as a "Teacher's value orientation," teachers in the serenity and conservatism and disengagement stages evaluated this dimension as more important in their work than teachers with less experience. The fourth stage of the Huberman model has two sub-types. The first is the stage of clarity, cheerfulness and distant relationships, which is characterized mainly as the result of the experiment stage (the third stage in the model) 
and in which the gradual loss of energy and enthusiasm is compensated by greater selfreliance and self-acceptance (Valenčič Zuljan, 1999, p. 118). The second stage is characterized by a lack of enthusiasm and the reduction of professional ambitions (Lya Kremen Hayon in Beijaard, 1995). For teachers in the conservatism stage, serenity and tranquility are characteristic, but there may also be intensity (Huberman, 1992, p. 127). Based on this, the study results can be interpreted as the teachers in these two stages focus more on the educational dimension in the class. Of course, this does not mean that a teacher dedicates less attention to the educational curriculum of the lesson. Instead, more than in continuous tracking progress in native language, it is directed toward educational work with students, and where, ultimately, teachers who have gained rich experience over years of teaching also feel more confident, and therefore, are less likely to resort to formal measures, which are used more by teachers with fewer years of service. Similar findings were found in other studies. Zlatković et all. (2012) studied the role of the teacher in the learning process and found that older teachers feel more successful in their role as a regulator of social relations in the classroom, as well as in the role of a partner in emotional interaction with pupils. In addition, in the role of a partner in emotional interaction with pupils, teachers with several years of service have been evaluated as successful (see also p. 382). From the results, Zlatković and colleagues conclude that teachers with more experience and those with several years of work experience feel more competent to perform roles that mostly relate to social relationships in class and emotional (affective) communication (Zlatković et all. (2012), p. 382). An important part of the professional identity of the teacher is the subject the teacher teaches, as well as the teacher's awareness of the status of the subject that he or she teaches (Day, Kington, Stobart, and Sammons, 2006, p. 607). That is why we examined whether there is a difference in teachers' understanding of their own role in the subject area. The teachers were classified into four groups (Language, Natural Sciences, Social Sciences, and Other) based on subject area. Statistically significant differences occurred in three dimensions: "Precise planning of lessons," "Taking into account the specificity of a class," and "Teacher's value orientation." The first two dimensions fall into the construct Teacher's Didactic Excellence and the third in the Teacher's Pedagogical Excellence con- struct. For the other dimensions, there were no statistically significant differences. The items in the dimensions Precise teaching planning and Teacher's value orientation were the highest evaluated by teachers from the category Others, followed by Language teachers and Natural Sciences teachers. The lowest rated in this dimension were Social Science teachers. Teachers in the Other category assessed the items that relate to the teacher's preparation for classes and their performance statistically significantly higher. The items on the questionnaire were universal, meaning that they were included in all subjects in gymnasiums. Therefore, we were surprised by the results for teachers of subjects that can be classified as in-between educational subjects: Great importance was attributed to the role of the teacher's didactic excellence. The third dimension, in which there were statistically significant differences, was rated the highest by Language teachers, followed by Other, Social Sciences, and Natural Sciences teachers. Poom-Valickis, 2012 , p. 239 found that mathematics teachers more often use metaphors linked to the role of teachers as a didactic expert, and fewer metaphors that relate to the role of teacher as a pedagogic expert, while English teachers use metaphors linked to the role of the teacher as a didactic expert and the role of the teacher as a pedagogic expert, more equally. The author concluded that the differences are probably due to the nature of the subjects themselves and that mathematics teachers rely more on the didactic role of the teacher, because they need didactic knowledge in order to make math more interesting and accessible to students. We agree that teachers understand their role first through the subject they teach, which is why we also think that the study showed statistically significant differences. However, we would like to highlight another finding. Teachers in this study, irrespective of subject area, evaluated the items in the dimension "Teacher's personal orientation." These items were the assertions "I am resolute," "I am consistent," and "In the classroom, I have clearly set rules for discipline and behavior." These results show that teachers define their professional identity and consequently, their role through personality traits. Other authors who studied teachers' professional development, such as Kelchtermans (in Day et al., 2006) discussed self-esteem (how teachers describe themselves through their professional story) and the self-esteem of the teacher (selfreflection of the teacher, how one sees oneself or is seen by others). Beijaard et all. (2004), 
however, stated that a teacher's professional identity contains personal and content perspectives, and teachers are expected to think and act professionally but not simply by internalizing the professional characteristics that include prescribed knowledge and behavior. Teachers differ (in the same way as the results of this study) in the way they face these characteristics, and the latter depends on how teachers personally agree with the traits (Beijaard et all. (2004), p. 122).

\section{CONCLUSIONS}

In the study, similarly to other authors (Goodson and Cole 1994, Volkmann and Anderson 1998), we proceeded from the starting point that one of the important elements on which teachers build their professional identity is the role they attribute to themselves. However, the key findings of this study can be summarized in three points: We found that teachers with several years of service experience feel better qualified to perform their duties. Most teachers feel qualified to perform tasks related to planning and teaching, followed by educational disciplinary behavior, and teachers, regardless of years of service, feel least qualified to write professional articles. When studying the impact of work experience on teachers' roles, we found that teachers with more work experience evaluated the assertions related to their educational activity, at the level of relationships and within the planning and delivery of lessons, statistically significantly higher than teachers with less work experience. On the first item, more experienced teachers rated items such as "to give students the opportunity to participate in the formulation of common rules in the classroom" and "to make decisions about resolving disciplinary offenses together with students" higher. In the context of content, however, teachers with more work experience responded that when planning their lessons, they also think about the educational effect that can be achieved through the content to emphasize the valuable dimension of the learning content in the discussion of the content and that students encourage sensitivity to experience artistic works and artistic expression.

In the framework of the research, we also identified the influence of the subject area on teachers' understanding of their own role as teachers. There were differences between teacher groups in different subject areas, which are those attributed to teachers of a particular subject area of greater or lesser importance. Within the same research question, we also found that teachers define their professional identity and consequently, their role through their personality traits. This finding is important in the study of teachers' professional identity and their professional development, which shows that we must not ignore teachers' personality traits, as they play an important role in teachers' professional development and identity.

We also wanted to draw attention to the various aspects and factors that make up and determine the role of teachers, thus building together their professional identity and affecting their professional development. The latter begins with their education and then changes and upgrades during the career path. Therefore, it is important to equip future teachers with the necessary teaching and pedagogical skills at the university level as well. All three elements are equally important for teachers' performance. For the same reason, when studying teachers' professional development, all three elements should be treated equally. Teachers need to be aware of the factors that influence their professional identity and development. It is important that teachers pay attention to the changes that occur, that they are not afraid, and that teachers raise awareness and reflect to improve their performance, as well as reflect on their professional development.

\section{ACKNOWLEDGEMENTS}

I would like to express my gratitude to all teachers who participated in the survey realizing the significance and importance of this issue. I also want to thank the colleagues who supported me during preparation of this article.

\section{Conflict of interests}

The author declares no conflict of interest.

\section{REFERENCES}

Adams, S. R. (1970). Analysing the teacher's role. Educational Research, 12(2), 121-127. https://doi. org/10.1080/0013188700120205

Arnon, S. \& Reichel, N. (2007). Who is the ideal teacher? Am I? Similarity and difference in perception of students of education regarding the qualities of a good teacher and of their own qualities as teachers. Teachers and Teaching: theory and practice, 13(5), 441-464. https://doi. org/10.1080/13540600701561653

Beijaard, D. (1995). Teachers' Prior Experienc- 
(IJCRSEE) International Journal of Cognitive Research in Science, Engineering and Education

Vol. 6, No. 2, 2018.

es and Actual Perceptions of Professional Identity. Teachers and Teaching: Theory and Practice, 1(2), 281-294. https://doi. org/10.1080/1354060950010209

Beijaard, D., Meijer, P. C., \& Verloop, N. (2004). Reconsidering research on teachers' professional identity. Teaching and Teacher Education, 20(2), 107-128. https://doi.org/10.1016/j. tate.2003.07.001

Beijaard, D., Verloop, N, \& Vermunt, J. D. (2000). Teachers' perceptions of professional identity: an exploratory study from a personal knowledge perspective. Teaching and Teacher Education, 16(7), 749-764. https://doi.org/10.1016/S0742051X(00)00023-8

Ben-Peretz, M., Mendelsona, N., \& Kronb, F. W. (2003). How teachers in different educational contexts view their roles. Teaching and Teacher Education, 19(2), 277-290. https://doi.org/10.1016/ S0742-051X(02)00100-2

Buchberger, F., Campos, B. P., Kallos, D., \& Stephenson J. (Eds.) (2000). Green Paper on Teacher Education in Europe: High Quality Teacher Education for High Quality Education and Training. Thematic Network on Teacher Education in Europe, Fakultetsnämnden för lärarutbildning,Umea universitet. https://repositorio-aberto.up.pt/bitstream/10216/56472/2/14487.pdf

Calderhead, J., \& Robson, M. (1991). Images of teaching: Student teachers' early conceptions of classroom practice. Teaching \& Teacher Education, 7(1), 1-8. https://doi.org/10.1016/0742051X(91)90053-R

Day, C., Kington, A., Stobart, G., \& Sammons, P. (2006). The personal and professional selves of teachers: stable and unstable identities. British Educational Research Journal, 32(4), 601-616. https://doi.org/10.1080/01411920600775316

Fullan, M. (1993). Change forces. Probing the Depths of Educational Reform. London: The Falmer Press. http://files.hbe.com.au/samplepages/ CO2639.pdf

Fullan, M. and Hargreaves, A. (2000). Za kaj se je vredno boriti v naši šoli? [What's worth fighting for in our school?]. Ljubljana: Zavod Republike Slovenije za šolstvo.

Gjedia, R., \& Gardinier, M. P. (2018). Mentoring and teachers' professional development in Albania. European Journal of Education, 53(1), 102-117. https://doi.org/10.1111/ejed.12258

Goodson, I. F., \& Cole, A. L. (1994). Exploring the teacher's professional knowledge: Constructing identity and community. Teacher Education Quarterly, 21(1), 85-105. https://www.jstor.org/ stable/23475536

Huberman, M. (1992). Teacher development and instructional mastery. In: A. Hargreaves \& M. G. Fullan (ed.) Understand Teacher Development (pp. 122-142). New York: Teachers College Press.

Kagan, M. D. (1992). Professional Growth Among Preservice and Beginning Teachers. Review of Educational Research, 62(2), 129-169. https://doi. org/10.3102/00346543062002129

Kalin, J. (2006). Učitelji (bodočih) učiteljev na Filozofski fakulteti v partnerstvu s šolami [Teaching (future) teachers at the Faculty of Arts in partnership with schools]. In: C. Peklaj (ed). Teorija in praksa $v$ izobraževanju učiteljev [Theory and practice in teacher education] (pp. 173-182).
Ljubljana: Center za pedagoško izobraževanje Filozofske fakultete Univerze v Ljubljani.

Katalog programov nadaljnjega izobraževanja in usposabljanja strokovnih delavcev $v$ vzgoji in izobraževanju za šolsko leto 2016/2017 [Catalogue of further education and training of professional workers in education for the school year 2016/2017]. (2016). Ljubljana: Ministrstvo za izobraževanje, znanost in šport. Retrieved from: https://lim3.mss.edus.si/katis/Katalogi/ KATALOG1617.pdf

Korthagen, F. A. J. (2004). In search of the essence of a good teacher: towards a more holistic approach in teacher education. Teaching and Teacher Education, 20(1), 77-97. https://doi.org/10.1016/j. tate.2003.10.002

Kovač Šebart, M. (2002). Samopodobe šole: konceptualizacija devetletke [Self-image of the school: Conceptualization of the nine year school]. Ljubljana: Zavod Republike Slovenije za šolstvo: Znanstveni inštitut Filozofske fakultete.

Kunst, E. M., van Woerkom, M., \& Poell, R. F. (2018). Teachers' goal orientation profiles and participation in professional development activities. Vocations and Learning, 11(1), 91-111. https://doi. org/10.1007/s12186-017-9182-y

Lachner, A., Jarodzka, H., \& Nückles, M. (2016). What makes an expert teacher? Investigating teachers' professional vision and discourse abilities. Instructional Science 44(3), 197-203. https://doi. org/10.1007/s11251-016-9376-y

Makovec Radovan, D. (2017). Pojmovanja vloge učitelja $\mathrm{V}$ procesih načrtovanja in izvajanja pouka $\mathrm{v}$ srednješolskem izobraževanju. Doctoral dissertation. [Conception of the role of the teacher in the process of planning and conducting instruction in secondary education. $\mathrm{PhD}$ Dissertation]. Univerza v Ljubljani, Filozofska fakulteta, Oddelek za pedagogiko in andragogiko.

Marentič Požarnik, B. (2006). Okvirni seznam ključnih kompetenc/zmožnosti [Indicative list of key competences]. In: XV Strokovno srečanje ravnateljic in ravnateljev. Osnovno šolstvo. $[X V$ Expert Meeting of primary school principals]. Ljubljana: Ministrstvo za šolstvo in šport.

McRobbie, C.J., \& Tobin, K. (1995). Restraints to reform: the congruence of teacher and student actions in a chemistry classroom. Journal of Research in Science Education, 32(4), 373-385. https://doi.org/10.1002/tea.3660320406

Muršak, J., Javrh, P., \& Kalin, J. (2011). Poklicni razvoj učiteljev [Professional development of teachers]. Ljubljana: Znanstvena založba Filozofske fakultete.

Nias, J. (1989). Teaching and the self. In: M. L. Holly \& C. S. McLoughlin (Eds.), Perspective on teacher professional development (pp. 151-171). London: Falmer Press.

Pajak, E. and Blase, J. J. (1989). The Impact of Teachers' Personal Lives on Professional Role Enactment: A Qualitative Analysis. American Educational Research Journal Summer, 26(2), 283-310. https://doi.org/10.3102/00028312026002283

Pajares, M. F. (1992). Teachers'Beliefs and Educational Research: Cleaning Up a Messy Construct. Review of Educational Research, 62(3), 307-332. https://doi.org/10.3102/00346543062003307

Podgornik, V., \& Vogrinc, J. (2017). The role of headteachers, teachers, and school counsellors in the 
system of quality assessment and assurance of school work. SAGE Open, 7(2), 1-13. https:// doi.org/10.1177/2158244017713239

Poom-Valickis, K., Oder, T., \& Lepik, M. (2012). Teachers' Beliefs Regarding their Professional Role: a Gardener, Lighthouse or Circus Director? Procedia - Social and Behavioral Sciences, 69, 233-241. https://doi.org/10.1016/j. sbspro.2012.11.404

Radovan, M. (2011). The relation between distance students' motivation, their use of learning strategies, and academic success. Turkish Online Journal of Educational Technology, 10(1), 216222. https://files.eric.ed.gov/fulltext/EJ926571. pdf

Radovan, M., \& Kristl, N. (2017). Acceptance of technology and its impact on teacher's activities in virtual classroom: integrating UTAUT and CoI into a combined model. Turkish online journal of educational technology, 16(3), 11-22. http:// www.tojet.net/volumes/v16i3.pdf\#page $=21$

Razdevšek Pučko, C. and Rugelj, J. (2006). Kompetence $\mathrm{v}$ izobraževanju učiteljev [Competences in teacher education]. V: Tancig, S. in Devjak, T. (ed.), Prispevki $k$ posodobitvi pedagoških studijskih programov [Contributions to the modernisation of pedagogical study programme]. Ljubljana, Pedagoška fakulteta, 30-44.

Rodrigues, L. D. A. D., de Pietri, E., Sanchez, H. S., \& Kuchah, K. (2018). The role of experienced teachers in the development of pre-service language teachers' professional identity: Revisiting school memories and constructing future teacher selves. International Journal of Educational Research, 88, 146-155. https://doi.org/10.1016/j. ijer.2018.02.002

Samuel, M., \& Stephens, D. (2000). Critical dialogues with self: Developing teacher identities and roles - a case study of South Africa. International Journal of Educational Research, 33(5), 475-491. https://doi.org/10.1016/S08830355(00)00030-6

Šteh, B., \& Kalin, J. (2006). Pogledi diplomantov in študentov Filozofske fakultete na načine dela pri predmetih pedagoškega usposabljanja [The views of graduates and students of the Faculty of Arts in ways of working in the subjects of pedagogical training]. In: C. Peklaj (Ed.). Teorija in praksa v izobraževanju učiteljev [Theory and practice in teacher education] (79-90). Ljubljana: Center za pedagoško izobraževanje pedagoške fakultete Univerze v Ljubljani.

Tobin, K., \& LaMaster, S. (1995). Relationships between metaphors, beliefs and actions in a context of science curriculum change. Journal of Research in Science Teaching, 32(3), 225-242. https://doi.org/10.1002/tea.3660320304

Valenčič Zuljan, M. (1999). Kognitivni model poklicnega razvoja študentov razrednega pouka. Doktorska disertacija [Cognitive model of professional development of students of class instruction study programme. PhD Dissertation]. Univerza v Ljubljani, Filozofska fakulteta, Oddelek za pedagogiko.

Valenčič Zuljan, M. (2001). Modeli in načela učiteljevega profesionalnega razvoja [Models and principles of the teacher's professional development]. Sodobna pedagogika, 52(2), 122 141.

Volkmann, M. J., \& Anderson, M. A. (1998). Creating professional identity: Dilemmas and metaphors of a first-year chemistry teacher. Science Education, 82(3), 293-310. https://doi.org/10.1002/ (SICI) 1098-237X(199806)82:3<293::AIDSCE1>3.0.CO;2-7

Yung, B. H. W. (2001). Examiner, Policeman or Students' Companion: teachers' perceptions of their role in an assessment reform. Educational Review, 53(3), 251-260. https://doi. org/10.1080/00131910120085856

Zlatković, B. Stojiljković, S., Djigić, G., \& Todorović, J. (2012). Self-concept and teachers professional roles. Procedia - Social and Behavioral Sciences, 69, 377-384. https://doi.org/10.1016/j. sbspro.2012.11.423

\section{APPENDIX}

Some examples of items related to work of the teacher:

\begin{tabular}{l}
\hline I plan the lesson in detail. \\
\hline I structure lessons after didactic stages. \\
\hline I write preparation for each lesson individually. \\
\hline I define operational learning objectives for each \\
lesson. \\
When planning classroom work, I take into \\
account the characteristics of students I teach. \\
\hline I'm consistent. \\
\hline I'm determined. \\
I give students the opportunity to participate in \\
drawing up common rules in the classroom. \\
\hline I constantly improve professionally. \\
\hline I bring new developments from the field of my \\
expertise into lessons. \\
In my professional pedagogical work, I strictly \\
observe the formal framework of rules laid \\
down by law and other documents. \\
\hline
\end{tabular}

